\title{
PENGARUH KINERJA KEUANGAN PERUSAHAAN \\ TERHADAP OPINI GOING CONCERN
}

(Studi Empiris Pada Perusahaan Manufaktur Yang Terdaftar Di Bursa Efek

Indonesia Tahun 2015-2017)

\section{JULIAN MARADINA}

Universitas Pamulang

*Email : jmaradina@yahoo.co.id

\begin{abstract}
The following research discusses analysis and discusses company financial planning in ongoing audit opinion. In the following research the method used is quantitative. The testing of the hypothesis in the research and the method used is logistic regression analysis using the version 22.0 Statistical Package for the Social Sciences (SPSS) program. The following research uses a purposive sampling technique, producing 26 (twenty six) manufacturing companies for 3 years so that the total sample is 78. The results of the study, liquidity which is proxied by the current ratio does not affect Going Concern Audit Opinion. The profitability of the return on asset (ROA) proxy has no effect on the going-concern audit opinion. Solvency of the debt proxy to total assets (DTA) has an influence on the going-concern audit opinion.
\end{abstract}

Keywords: Financial Performance, Going Concern Audit Opinion

\section{PENDAHULUAN}

\section{Latar Belakang Penelitian}

Kepentingan investor, memiliki hak yang sangat penting. Dalam hal ini investor menyumbangkan modalnya untuk mendanai kegiatan perusahaan. Sebelum investor menyumbangkan investasi ke perusahaan, hal pertama yang menjadi pemikiran yaitu terkait dengan kelangsungan hidup (going concern) perusahaan. Perusahaan yang menerbitkan dalam financial report akan menjadi pertimbangan dalam laporan keuangan perusahaan.

Memperbaiki lingkungan dalam perusahaan yang mendukung perusahaan dalam menjalankan dan menjalankan usahanya. Dalam kondisi keuangan yang baik dalam kondisi kondisi baik maka akan memicu operasional perusahaan yang lebih bagus. Kondisi keuangan negara yang tidak baik maka dapat membuat 
perusahaan kesulitan dalam mengembangkan usahanya. Keuangan yang buruk menjadikan investor untuk berfikir kembali jika ingin melakukan investasi.

Perusahaan berkewajiban membuat, melaporkan kondisi keuangan perusahaan dalam periode tertentu ke dalam laporan keuangan. Dan dianalisa sehingga akan diketahui kondisi perusahaan sekarang. Di annual report menjelaskan dapat ditentukan hal akan dilakukan saat ini dan kedepannya. Laporan keuangan juga dapat membahas kelemahan dan kekuatan dalam perusahaan. Dalam kaitannya dengan pertimbangan perusahaan akan mempertahankan perencanaan untuk perusahaan yang lama, perlu auditor untuk mencari bantuan dalam mendukung perusahaan yang diharapkan. Auditor harus segera mengungkapkan hal tersebut kepada publik. Jika auditor tidak mengungkapkan maka akan menarik minat masyarakat atas pihak pemakai laporan keuangan, karena akan membuat salah dalam pengambilan keputusan dalam berbisnis.

Dalam penilaian terhadap perusahaan, perusahaan harus mempertahankan, auditor wajib mencari banyak informasi termasuk info yang bersifat kuantitatif, auditor menggunakan rasio keuangan seperti likuiditas, solvabilitas dan profitabilitas. Kinerja keuangan dalam hal ini yaitu likuiditas atas proksi rasio lancar, profitabilitas atas proksi pengembalian aset, dan juga solvabilitas atas proksi utang terhadap total aset. Likuiditas atau modal kerja yaitu rasio yang dipergunakan menghitung likuiditasnya sebuah perusahaan. Caranya membandingkan total pembelanjaan lancar dengan passiva lancar (pembelanjaan pendek) Kasmir (2015: 130). Profitabilitas yaitu usaha perusahaan mendapatkan laba dengan seluruh ketersediaan dengan seluruh ketersediaan yang tersedia (Syamsuddin, 2001: 63). Solvabilitas adalah rasio dipergunakan menghitung yang dibeli perusahaan yang dibiayai dengan utang (Kasmir, 2015: 151). Sampelnya perusahaan manufaktur yang diterbitkan (BEI) pada periode 2015-2017. Judulnya diambil "Kinerja Keuangan Perusahaan Terhadap Opini Audit Going Concern"

\section{Perumusan Masalah}

1. Apakah likuiditas yang diproksikan rasio lancar berpengaruh signifikan terhadap opini going concern?

2. Apakah profitabilitas atas proksi pengembalian aset berpengaruh signifikan terhadap opini audit going concern?

3. Apakah solvabilitas atas proksi utang terhadap total aset akan berpengaruh signifikan terhadap opini audit going concern? 


\section{TINJAUAN PUSTAKA}

Oleh Fahmi (2013: 142) GAAP (Prinsip Akuntansi Umum yang diterima), kinerja keuangan yang difokuskan ke rasio likuiditas yang dipakai adalah rasio lancar, rasio profitabilitas yang dipakai adalah pengembalian aset, dan rasio solvabilitas yang dipakai adalah utang terhadap total aset.

\section{Likuiditas}

Rasio likuiditas yang juga merupakan rasio modal kerja di mana rasio diperuntukkan untuk menghitung likuiditasnya perusahaan memperbandingkan komponen yang ada di perbandingan, yaitu total pembelanjaan dengan passiva lancar (pembelanjaan pendek) Kasmir (2015: 130). Jika perusahaan tidak ada kemampuan untuk melunasi, secara singkatnya, maka operasional mengalami gangguan dan dapat menyebabkan auditor ragu mengenai perusahaan mampu atau tidak mampu dalam mempertahankan keberlanjutan usahanya. Auditor menganggap sebagai pihak independen mengajukan permohonan penilaian financial di annual report dapat digunakan pihak prinsipal untuk right business decision making.

\section{Profitabilitas}

Profitabilitas adalah usaha perusahaan dalam menghasilkan profit dengan semua ketersediaan yang ada (Syamsuddin, 2001: 63). Laba yang digunakan sebagai penilaian dari perusahaan. Company profitability juga menentukan business decisions from investors.

\section{Solvabilitas}

Solvabilitas, rasio yang dipakai menghitung yang dibeli perusahaan yang menggunakan dengan utang (Kasmir, 2015:151). Solvabilitas sesuai total yang dikeluarkan perusahaan untuk pihak ketiga. Pembanding untuk Solvabilitas utang terhadap jumlah aset. Tingginya solvabilitas, semakin banyak yang mempertanyakan kondisi financial company yang lebih baik dan berakibat ketidak pastian pembelanjaan perusahaan.

\section{Opini Audit Going Concern}

Keberlangsungan hidup perusahaan merupakan di mana unit mampu dalam mengatasi kesulitan waktu tertentu, di mana tidak melebihi satu periode laporan keuangan (SPAP, 2001). Ketidakpastian terhadap keberhasilan kelangsungan perusahaan, di sini auditor memikirkan memberikan opini yang akan terjadi. "SA Seksi 341, PSA No. 30 (IAPI, 2011) di dalam SPAP, opini audit yang termasuk dalam opini Going Concern (GC) adalah Tidak Memenuhi Syarat 
dengan Bahasa Penjelasan / Penekanan Paragraf Materi, Opini yang Memenuhi Syarat, Opini yang Merugikan dan Opini Sangkalan (IAPI, 2011) dalam Pradika (2017).”

\section{Hal-hal Mempengaruhi Opini Audit Going Concern}

Dalam pengauditan, auditor memberikan info tentang masalah ataupun persyaratan berkaitan dengan pelaporan mengenai ketidakpercayaan tentang kemampuan company dalam keberhasilan dalam waktu yang sesuai. Signifikan atau tidaknya akan tergantung pada situasi dan beberapa yang akan ditinjau (IAPI, 2011) di Pradika (2017). Beberapa contoh yang dapat menimbulkan keraguan yang signifikan tentang pertimbangan keberlangsungan usaha diantaranya: arus kas yang selalu mengalami negatif; pinjaman yang sudah jatuh tempo; perusahaan selalu mengalami kerugian; mengalami kesulitan dalam melunasi kreditur yang sudah jatuh tempo; adanya ketidak percayaan dari pihak ketiga dalam pemberian pinjaman lagi; kegagalan perusahaan dalam berinovasi dan mengembangkan perusahaan dan juga bisa dikarenakan terlibat kasus hukum.

\section{Kerangka Pemikiran}

Berkaitan variabel independen dan dependen, yaitu Likuiditas, Profitabilitas, Solvabilitas kemudian Opini Audit Going Concern. Untuk lebih jelasnya dibuat bagaikan pemikiran seperti gambar berikut:

Kinerja Keuangan Perusahaan

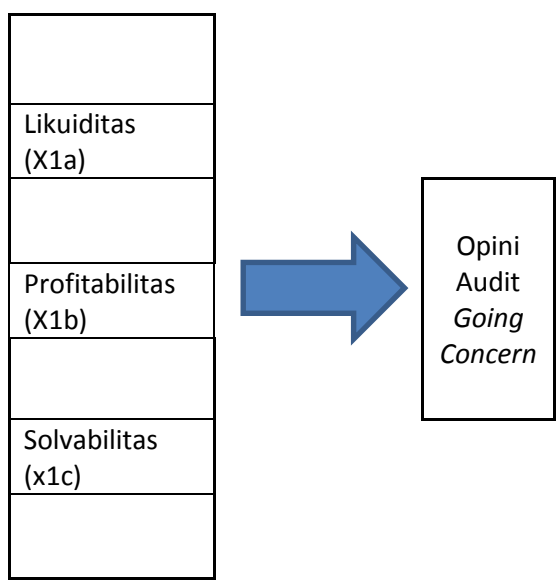




\section{Pengembangan Hipotesis}

Hipotesis pertama dari penelitian sebelumnya yang sudah dilakukan oleh Pradika (2017) yang membuktikan likuiditas negatif pengaruhnya ke opini going concern. Likuiditas yang kurang/kecil akan membuat company memiliki kemampuan dalam pelunasan permintaan singkat yang sesuai dengan kebutuhan, meningkatkan akuntabilitas si pemeriksa dalam pemberian opini going concern dapat mendukung keberlangsungan hidup company. Oleh karenanya diajukan hipotesis:

H1a: Diduga Likuiditas berpengaruh terhadap penerimaan opini audit going concern.

Hipotesis kedua dari sebelumnya yang diteliti oleh Arma (2013) membuktikan profitabilitas berkaitan dengan penerimaan opini audit going concern. Oleh karenanya diajukan hipotesis:

$\mathrm{H} 1 \mathrm{~b}$ : Diduga profitabilitas yang diterima berpengaruh terhadap opini audit going concern.

Hipotesis ketiga ini didukung Setiawan \& Suryono (2015), menyetujui bahwa solvabilitas yang diproksikan dengan rasio hutang terhadap aset berpengaruh terhadap opini going concern. Oleh karenanya diajukan hipotesis:

H1c: Diduga solvabilitas ditentukan terhadap penerimaan opini audit going concern.

\section{METODE PENELITIAN}

Jenis penelitian yang penulis lakukan adalah kuantitatif. Disetujui dengan penelitian kuantitatif adalah penelitian dengan menggunakan sekumpulan data yang ada untuk dianalisis. Terdapat empat variabel yang diteliti, yaitu variabel bebas (independen) adalah likuiditas (X1a), profitabilitas (X1b), solvabilitas (X1c) dan variabel yang diperlukannya (dependen) adalah opini audit going concern $(\mathrm{Y})$.

\section{Likuiditas}

Pengukuran untuk menghitung likuiditasnya suatu perusahaan dengan membandingkan komponen yang ada di dalam perbandingan, yaitu total pembelanjaan dengan passiva lancar (pembelanjaan pendek) Kasmir (2015: 130). Perbandingan yang dilakukan adalah aset lancar dibagi dengan kewajiban lancar.

\section{Profitabilitas}

Pengukuran untuk membandingkan profitabilitas disini menggunakan rumus pengembalian aset yaitu laba bersih dibagi dengan total aset. 


\section{Solvabilitas}

Pengukuran yang digunakan untuk menghitung solvabilitas yaitu dengan hutang ke total aset yaitu total kewajiban dibagi total aset.

\section{Variabel Terikat (Dependen)}

Digunakan variabel dummy. Opini audit going concern dengan kode 1 (opini wajar tanpa pengecualian dengan bahasa penjelas, opini wajar dengan pengecualian, opini tidak wajar, atau tidak mempercayai pendapat), dan opini audit no-going concern diberi kode 0 (opini wajar tanpa pengecualian). Pendapat yang wajar tanpa pengecualian perlu penjelasan yang terkait dengan going concern atau tidak dengan "keraguan yang substansial kemampuan (entitas) untuk melanjutkan usaha". Jika dijelaskannya bukan karena kepedulian maka berkode 0 .

\section{Populasi dan Sampel}

Populasinya perusahaan manufaktur yang terdaftar di Bursa Efek Indonesia (BEI) tahun 2015 hingga 2017, yaitu sebanyak 154 perusahaan. Dan sampel yang diambil dengan menggunakan metode purposive sampling,yaitu berdasarkan kriteria yaitu terdaftar di BEI selama tahun pengamatan tahun 2015-2017, sebelum tahun 2015 sudah terdaftar, menerbitkan annual report audited, dan terdapat kesulitan keuangan sekurang-kurangnya dua periode laporan keuangan tahun 2015-2017.

\section{HASIL DAN PEMBAHASAN}

Jumlah perusahaan manufaktur yang terdaftar di BEI pada tahun 2015 2017 berjumlah 154 perusahaan. Kriterianya, yaitu menentukan pengambilan sampel berdasarkan karakteristik tertentu yang sudah dimiliki sebelumnya untuk memberikan informasi secara optimal. Dengan teknik tersebut, sampel per 26 perusahaan yang dianggap layak untuk dijadikan objek penelitian. Penelitian dilakukan membahas tentang perusahaan yang memiliki keraguan terhadap perusahaan dalam mempertahankan kesulitan, auditor harus memperhatikan aspek likuiditas, profitabilitas dan solvabilitas.

\section{Analisis Uji Statistik Deskriptif}

Hasil uji statistik deskriptif untuk setiap variabel terdapat pada tabel ini: 
Tabel 3.1 Uji Statistik Deskripstif

\begin{tabular}{|l|l|l|l|l|l|}
\hline & $\mathrm{N}$ & Minimum & Maximum & Mean & Standar Deviasi \\
\hline & & & & & \\
\hline Likuiditas & 78 & .033705 & 13.349160 & 1.73127328 & 2.115345477 \\
\hline & & & & & \\
\hline Profitabilitas & 78 & -3.417869 & .063355 & -.11261757 & .398495342 \\
\hline & & & & & \\
\hline Solvabilitas & 78 & .084803 & 14.935870 & 1.16869803 & 2.020921472 \\
\hline $\begin{array}{l}\text { Opini Audit Going } \\
\text { Concern }\end{array}$ & 78 & .000000 & 1.000000 & .17948718 & .386243640 \\
\hline & & & & & \\
\hline
\end{tabular}

Berdasarkan tabel tersebut menunjukkan total data pada setiap variabel yang valid adalah 78 data. Variabel likuiditas, diterima dengan rasio lancar dari 78 sampel data dapat dimiliki nilai minimum sebesar 0,033705 , nilai maksimumnya sebesar 13,349160 diberikan oleh Jaya Pari Steel Tbk. Nilai rata-rata dari variabel likuiditas sejumlah 1,73127328 dengan standar deviasi sejumlah 2,115345477.

Variabel profitabilitas, yang diukur dengan pengembalian atas aset (ROA), dari 78 sampel data dapat dimiliki nilai minimum sebesar -3,417869 yang diperoleh oleh Panasia Indo Resources Tbk, sedangkan nilai maksimum sebesar 0,063355 digunakan oleh Ever Shine Tex Tbk. Nilai means (rata-rata) dari variabel profitabilitas sejumlah -0,11261757 dengan standar deviasi sejumlah 0,398495342 .

Solvabilitas, dihitung dengan utang terhadap total aset, dari 78 sampel data dapat dimiliki nilai minimum sebesar 0,084803, maksimum sejumlah 14,935870 diberikan oleh Panasia Indo Resouces Tbk. Nilai rata-rata dari solvabilitas sejumlah 1,16869803., standar deviasi sejumlah 2,020921472.

Variabel Opini audit going concern, dapat diterima with penilaian wajar tanpa pengecualian dengan bahasa penjelas, pendapat wajar dengan pengecualian, pendapat tidak wajar, atau tidak mempercayai pendapat untuk perusahaan oleh auditor. Dari 78 sampel data dapat dimiliki nilai minimum sebesar 0,000000 dimiliki oleh Mustika Ratu Tbk, sedangkan nilai maksimum sebesar 1, 000000 dimiliki oleh Argo Pantes Tbk. Nilai rata-rata (rata-rata) dari opini audit going concern sebesar 0,17948718 dengan standar deviasi sejumlah 0,386243640. 
Analisis Uji Multikolinearitas

Berikut hasil uji multikolearitas:

Tabel 3.2 Hasil Uji Multikolinearitas

\begin{tabular}{|l|l|l|}
\hline \multirow{2}{*}{ Model } & \multicolumn{2}{|l|}{$\begin{array}{l}\text { Statistik } \\
\text { Kolinieritas }\end{array}$} \\
\cline { 2 - 3 } & Toleransi & \multicolumn{1}{l|}{ VIF } \\
\hline & & \\
Likuiditas & .902 & 1.108 \\
Profitabilitas & .261 & 3.826 \\
Solvabilitas & .212 & 4.706 \\
\hline
\end{tabular}

Berdasarkan tabel di atas menunjukkan variabel Likuiditas, Profitabilitas, dan Solvabilitas memiliki toleransi nilai lebih dari 0,10 yang berarti terkait dengan independen. Hasil perhitungan Variance Inflation Factor (VIF) memperlihatkan variabel Likuiditas, Profitabilitas, dan Solvabilitas memiliki nilai VIF kurang dari 10 yang berarti tidak diperlukan antar variabel independen. Menurut nilai toleransi dan VIF, dapat disimpulkan tidak terdapat multikolinearitas antar variabel independen sehingga terbebas dari masalah multikolinearitas.

\section{Uji Hipotesis}

Pengujian Secara Parsial

Teknik yang digunakan regresi logistik dengan hubungan parsial diantara variabel independen terhadap variabel dependen. Pengujian parsial menggunakan signifikansi 0,05 .

Jika probabilitas $<0,05$ maka $\mathrm{H}$ diterima

Jika probabilitas $>0,05$ maka $\mathrm{H}$ ditolak

Hasil analisisnya terdapat tabel ini:

Tabel 3.3 Uji Parsial

\begin{tabular}{|l|l|l|l|l|l|l|}
\hline & B & S.E & Wald & df & Sig. & Exp(B) \\
\hline Likuiditas & $-0,055$ & .270 & .042 & 1 & .838 & .947 \\
\hline Provitabilitas & -7.852 & 5.431 & 2.090 & 1 & .148 & .000 \\
\hline Solvabilitas & -943 & .475 & 3.942 & 1 & .047 & .389 \\
\hline
\end{tabular}

Dari tabel di atas, dapat dirumuskan, regresi, logistik, likuiditas, profitabilitas, solvabilitas terhadap opini audit akan menjadi perhatian berikut: 


\section{Pengujian Hipotesis Pertama (H1)}

Berdasarkan hasil regresi, likuiditas mempunyai nilai koefisien regresinya $-0,055$ dan Sig. $0,838>$ alpha 0,05 yang artinya variabel likuiditas tidak memiliki pengaruh kepada variabel opini audit going concern. Dengan demikian, dapat menolak hipotesis pertama (H1) ditolak. Hal ini tidak sesuai hasil analisis dari Arma (2013) menyatakan likuiditas yang diproksikan dengan rasio saat ini berpengaruh negatif terhadap opini audit going concern.

Pengujian Hipotesis Kedua (H2)

Berdasarkan hasil regresi, variabel profitabilitas nilai koefisien regresinya 7.852., Sig. 0,148> alpha 0,05 yang artinya profitabilitas tidak pengaruh kepada variabel opini audit going concern. Maka demikian, dapat ditolak sebagai hipotesis kedua (H2) ditolak. Hal ini penelitian sebelumnya Arma (2013) dan Kurnia dan Suryono (2014) menyatakan bahwa profitabilitas yang diproksikan dengan pengembalian atas aset yang negatif terhadap pendapat akan terjadi. Hasil penelitian ini menyatakan keuntungan tidak berpengaruh kepada opini yang akan terjadi.

\section{Pengujian Hipotesis Ketiga (H3)}

Berdasarkan hasil regresi, variabel solvabilitas koefisien regresinya $-0,943$ dan Sig. 0,047 <alpha 0,05 yang berarti variabel solvabilitas berpengaruh negatif kepada variabel opini audit going concern. Maka, dapat disimpulkan sebagai hipotesis tiga $(\mathrm{H} 3)$ diterima. Berdasarkan penelitian sebelumnya, Setiawan dan Suryono (2015) memberitahukan solvabilitas yang diproksikan dengan rasio hutang terhadap aset berpengaruh signifikan kepada opini audit going concern. Dari penelitian ini memaparkan Solvabilitas membuktikan kepada penerimaan opini audit yang berlangsung. Solvabilitas yang dapat meningkatkan risiko company, prioritas pembayaran utang dan bunga. Hal ini tidak dapat menimbulkan keraguan dari auditor atas kemampuan yang akan menjadi perhatian perusahaan.

\section{KESIMPULAN DAN SARAN}

\section{Kesimpulan}

Penelitian ini dilakukan membuktikan pengaruh likuiditas, profitabilitas, solvabilitas terhadap Opini Audit Going Concern pada perusahaan manufaktur yang terdaftar di Bursa Efek Indonesia (BEI). Sampelnya 26 perusahaan manufaktur pada tahun 2015-2017, dipilih berdasarkan kriteria, yaitu: likuiditas yang diproksikan dengan rasio lancar tidak memiliki kontribusi terhadap opini going concern, profitabilitas yang diproksikan dengan pengembalian aset tidak 
memiliki pengaruh, dan solvabilitas yang diproksikan dengan hutang terhadap total aset (DTA) memiliki pengaruh terhadap opini going concern.

\section{Batasan}

Peneliti mempunyai batasan dalam penelitian ini, yaitu hanya menggunakan perusahaan manufaktur yang terdaftar di Bursa Efek Indonesia (BEI) sedangkan periode 2015-2017, sehingga penelitian ini hanya membahas tentang perusahaan manufaktur untuk periode 2015 hingga 2017.

\section{Saran}

1. Penelitian selanjutnya diharapkan dapat mencapai jumlah tahun pengamatan.

2. Penelitian selanjutnya dapat mengganti proksi likuiditas dengan rasio cepat, rasio kas dll. Proksi profitabilitas dengan return on investment, return on equity dll. Dan proksi solvabilitas dengan hutang terhadap ekuitas, hutang jangka panjang terhadap ekuitas dll.

3. Memperluas objek penelitian dengan menambah sampel perusahaan real estate ataupun jasa.

\section{DAFTAR PUSTAKA}

Agoes, Sukrisno. (2017). Auditing 1: Petunjuk Praktis Pemeriksaan Akuntan oleh Akuntan Publik. Jakarta: Salemba Empat

Alichia, Yashinta Putri. (2013). Pengaruh ukuran perusahaan, pertumbuhan perusahaan, dan audit tahun sebelumnya terhadap opini audit going concern. Jurnal Universitas Negeri Padang

Angrijani dan Zakaria. (2016). Pengaruh kinerja keuangan terhadap opini going concern. Jurnal Universitas Yapis Papua

Arma, Endra Ulkri. (2013). Pengaruh profabilitas, likuiditas, dan pertumbuhan perusahaan terhadap penerimaan opini audit going concern. Jurnal Universitas Negeri Padang.

Arens, A.A., J.E Randal, dan S.B Mark. (2008). Auditing dan Jasa Assurance. Jakarta: Erlangga.

Fahmi, Irham. (2013). Manajemen Kinerja: Teori dan Aplikasi. Bandung: CV. Alfabeta.

Ghozali, Imam. (2016). Aplikasi analisis multivariate dengan program IBM SPSS 21. Semarang: Badan Penerbit Universitas Diponegoro. 
Ilham, Ahmad Jaenal. (2015). Analisis Pengaruh Book Tax Difference terhadap pertumbuhan laba. Skripsi Universitas Pamulang.

Institut Akuntan Publik Indonesia. (2011). Standar Profesional Akuntan Publik. Jakarta: Salemba Empat.

Kasmir. (2015). Analisis Laporan Keuangan. Jakarta: PT Raja Grafindo Persada.

Kurnia dan Suryono. (2014). Pengaruh Kinerja Keuangan Perusahaan Terhadap Pemberian Opini Audit Going Concern. Jurnal Sekolah Tinggi Ilmu Ekonomi Indonesia (STIESIA) Surabaya.

Lie, Wardani, Pikir. (2016). Pengaruh likuiditas, solvabilitas, profabilitas, dan rencana menejemen terhadap opini audit going concern. Jurnal Universitas Katolik Widya Mandala Surabaya.

Lutfi, Muchamad. (2016). Pengaruh ukuran perusahaan, profabilitas, likuiditas, solvabilitas terhadap opini audit going concern. Jurnal Universitas Muhammadiyah Surakarta.

Sawir, Agnes. (2004). Kebijakan Pendanaan dan Restribusi Perusahaan. Jakarta: PT Gramedia Pustaka Utama.

Safitri, Riza. (2017). Pengaruh Kondisi Keuangan Perusahaan, Ukuran Perusahaan, Opinion Shopping, Kualitas Audit, Audit Client Tenure, Debt Default dan Audit Lag terhadap Penerimaan Opini Audit Going Concer. Jurnal Universitas Riau.

Sari, Soetikno. (2012). Analisa faktor-faktor yang mempengaruhi auditor dalam memberikan opini going concern. Jurnal Universitas Diponegoro.

Setiawan, dan Suryono. (2015). Pengaruh Pertumbuhan Perusahaan, Profitabilitas, Likuiditas, Dan Leverage Terhadap Opini Audit Going Concern. Jurnal Sekolah Tinggi Ilmu Ekonomi Indonesia (STIESIA) Surabaya.

Setyowati, Widhy. (2013). Strategi manajemen sebagai faktor mitigasi terhadap penerimaan opini going concern. Jurnal Universitas Diponegoro Semarang.

Sugiyono. 2016. Metode penelitian kuantitatif kualitatif: Kualitatif, Kuantitatif, dan $R \& D$. Bandung: CV. Alfabeta.

Sundjaja, R. S., dan Inge Barlian. (2003). Manajemen Keuangan: Perencanaan dan Analisis Keuangan. Jakarta: Literata Lintas Media.

Syamsuddin, L. (2001). Manajemen Keuangan Perusahaan: Perencanaan, Pengawasan dan Pengambilan Keputusan. Jakarta: PT. Raja Grafindo Persada.

Pradika, Rizka Ardhi. (2017). Pengaruh profitabilitas, likuiditas, dan ukuran perusahaan terhadap opini audit going concer. Skripsi Universitas Negeri Yogyakarta.

www.sahamok.com

www.idx.co 